\title{
THEORETICAL ASPECTS OF STUDYING THE IMAGE OF THE PRESENTER AS A KEY SEMANTIC UNIT OF TV PROGRAMS
}

\author{
Grigory Vakku ${ }^{1 *}$, Simona Lebedeva ${ }^{2}$, Lidia Malygina ${ }^{3}$, Natalia Lazutova ${ }^{4}$, \\ Dmitry Goncharov ${ }^{5}$
}

${ }^{1}$ Candidate of philological Sciences, associate Professor, Moscow state University of Humanities and Economics, Russia, vakku2006@rambler.ru, ORCID 0000-0001-7676-8962; SPIN-код: 3886-4740; AuthorID: 284494

${ }^{2}$ Candidate of philological Sciences, associate Professor Moscow state University of Humanities and Economics, Russia, lebedeva220461@yandex.ru, SPIN-код: 2308-8043; AuthorID: 929149

${ }^{3}$ Candidate of Philological Sciences, associate Professor, Lomonosov Moscow State University, Russia,9955140@gmail.com,ORCID 0000-0002-0056-8160; D-6901-2019;

SPIN-код: $5278-1225$

${ }^{4}$ Senior researcher of the Department of periodicals, Lomonosov Moscow State University, Russia, n.m.rom@yandex.ru, ORCID: 0000-0001-7524-1907; SPIN-код: 8551-2698

${ }^{5}$ Associate Professor of the Department of Informatics of the Russian Economic University G.V.

Plekhanov ", Russia, e-mail: vakkmar@mail.ru,

ORCID:0000-0002-3408-5036; SPIN-код: 7979-1150; AuthorID: 560483

${ }^{*}$ Corresponding Author

\begin{abstract}
In this paper, the authors analyzed the intellectual game show as a genre, considered television programs, including television game shows, where hosts are creators of the program as well. The authors identified typical behavior patterns of a presenter in front of the camera, the traits manifested by a presenter depending on the program's genre and format.
\end{abstract}

The topic that we have chosen for research is currently quite relevant, since the image of the leader of a certain intellectual game is unique, has distinctive features and certain specificity. The purpose of this paper is to consider the image of a presenter as the key semantic unit of a television program and identify its aspects.

To achieve this goal, we were assigned the following tasks: to consider the presenter's image as a key semantic unit of a television program; to reveal the specific features of the images of the leading original intellectual TV games.

The research methods used in this paper include observation, analysis and synthesis, comparison, generalization. The novelty of this work lies in the original theoretical and practical analysis and identification of the specific features of the images of the leading intellectual games as a type of television programs.

The authors of the article came to the conclusion that the host or author-host of an intellectual game must have a set of specific features: communicative and psychological abilities.

Keywords: TV journalism, journalist, TV program, audience, TV broadcast, image, author and presenter.

\section{INTRODUCTION}

The success of a television program, of an intellectual game show in particular, depends primarily on the presenter. The key component of a TV game show as well as of any other TV program of a different genre is 
its presenter. First, this paper reveals the concepts of "presenter" and "intellectual game show". An intellectual game show is a type of a TV game show in which contestants use their knowledge or logical thinking to win (Vakku, Zotov 2020). As a rule, in such programs, contestants have to answer questions from various areas of knowledge and fields. There are many intellectual game shows in the modern media, on television in particular, where winners get money or prizes. The key element of such TV programs is a contest or a game. In intellectual game shows contestants can compete as individuals or as a team. Additionally, the player can compete against the presenter, computer, or viewers.

A presenter is a media worker who works in front of the camera (TV) or on air (radio), personalizing the information they convey (Official website «Academician - dictionaries and encyclopedias»). Work experience is vital in this job. For television presenters, an essential success criterion is their appearance. For radio presenters, it is diction. For talk show presenters, it is a combination of both. A presenter not only presents news and other information to viewers, but they also focus the viewers' attention on important elements of the message with the help of intonation. Role behavior forms a particular screen manner.

Advantages of being a presenter: 1 . Communication with public figures; 2 . An opportunity to become a public figure; 3. High salary.

Disadvantages of being a presenter: 1. Little privacy; 2. A necessity to stay productive all day long; 3 . Psychological stress.

Communication with television and radio audiences does not imply a conversational process: to inform does not mean to conduct a dialogue.

\section{OPINIONS AND DISCUSSION}

A presenter is the key semantic unit of the program who can make it succeed or fail with the target audience. Using verbal and non-verbal means, a presenter can behave in different ways, creating their own unique image. Depending on the program genre, a presenter can:

- Inform, agitate, propagandize (as in the news programs "Vremya" ("Time"), "Vesti" ("News"), "Segodnya" ("Today"), etc.);

- Possess strong communication skills, be a good conversationalist and psychologist for the interview genre (examples: Vladislav Listyev ("Chas Pik", or "The Rush Hour"), Vladimir Pozner ("Pozner"), Boris Korchevnikov ("The Fate of a Man"), Yuri Dud ("VDud"), etc.);

- Help people solve personal social problems (Elena Proklova ("Housing and Communal Services"), Anastasia Melnikova ("Uchastok"), etc.);

- Act as a moderator of communication (Andrei Malakhov in the talk show "Live Broadcast", Dmitry Borisov in the talk show "Let Them Speak", etc.);

- Act as an expert in a particular narrow field (Elena Malysheva in the program about medicine and health "Living Healthy", lawyer Elena Dmitriyeva in the court show "Family Cases", scientific experts on Nauka (Science) TV channel, etc.);

- Provoke, create a conflict situation in the studio during a live broadcast (Vladimir Solovyov in the debate show "Poyedinok" ("Duel") and "Sunday Evening with Vladimir Solovyov", Artyom Sheinin in the sociopolitical talk show "Time Will Tell", etc.).

- Possess improvisation and intellectual skills, a broad outlook, erudition, a sense of humor, charisma, establish and maintain contact with a specific target audience, including children audience, generate and maintain the viewers' interest. These traits are manifested in entertainment programs (Ivan Urgant in "Evening Urgant", "Smak", residents of "Comedy Club", "Improvisation", presenters of "Prozhektorperiskhilton"), in educational and popular science programs (Alexander Pushnoy, Vladimir Markoni in "Galileo", Sergei Malozemov in "The Miracle of Technology", Dmitry Krylov in "Unlucky Notes", Leonid Parfyonov in "Namedni", in the online project "Parfenon"), in intellectual and entertainment game shows (Alexander Gurevich in "Hundred to One", Peter Kuleshov in "Svoya Igra" ("Your Game"), Vladimir Voroshilov and Boris Kryuk in "What? Where? When?") and in programs for kids (Sergei Suponev in "Marathon-15", "Star Hour", "Call of the Jungle", "The New Reality"), etc.

These and other behaviors of a presenter compose their image. The image manifests itself on multiple levels:

1. Eye gaze. Eye contact is very important. Eye gaze greatly influences the audience's interest in the person. The eye gaze of a presenter plays an important role when conducting an interview. Professional TV 
presenters tend to look directly in the eye, less frequently - use peripheral vision, which does not correspond to the social situation.

2. Speech. In information-analytical programs, popular science programs or programs intended for a specific target audience, a professional journalist should discuss the topics that could interest the viewers and use plain language.

The communication process is made up of four stages. The first stage is adaptation, or preparation for the upcoming conversation. The next stage is the conversation, which is the purpose of the meeting. The third stage is psychological relief reducing emotional stress. The final stage is the feelings experienced by the participants at the end of the communication process.

3. Pauses. Pausing performs several essential functions: physiological (deliberate breathing), semantic (it assesses the point of the utterance), evaluative (it characterizes the rationality of the sentence, psychological aspects).

From a professional point of view, pausing can be used by a presenter to show their attitude to what is happening on the air. Thus, journalist Vladimir Pozner in the program "Vremena" ("Times") often used speech pauses in combination with facial reactions in response to the interviewee's remarks, in combination with similar question forms, ironic, surprised facial expression. In this case, pausing marks the beginning of the formation of an author and presenter's image.

4. Intonation. Intonation helps the audience understand the true meaning of the remark. In terms of emotional shades and speech expressiveness, there are around twenty types of intonation reflecting different feelings. For example, Dmitry Dibrov in the music program "Anthropology" greeted in-studio guests coldly, detachedly and said goodbye rather warmly (Official website "YouTube video hosting. 25 years of NTV. Dmitry Dibrov's Anthropology program with the King and the Fool group»). With this contrast, he emphasized that his guest (as a rule, unusual, memorable) has to prove their originality and earn the right to this characteristic.

5. Body. Researcher A.M. Shesterina identifies multiple body signals and notes that their number is much greater than a vocabulary size (Official website «Internet archive of educational literature. The psychology of journalism. Study guide»). The TV presenters who actively work with in-studio guests are characterized by dominant behavior in communication situations, attentive listening postures (leaning forward, open arms, close distance). In order to make the music game program "Ugaday Melodiyu" ("Guess the Tune") more spectacular and dynamic, the show presenter Valdis Pelsh actively gesticulated when he greeted the viewers, introduced contestants, when a contestant quickly guessed the tune, and when he tried to give a clue to the player: guide them toward the correct answer by recalling the motif or the content of the song (Official website «YouTube video hosting. Official video archive of the VID TV company. Guess the melody. Issue of 27.10.2003»).

6. Clothes. There are some requirements in relation to the appearance of a journalist. A suit shouldn't be too revealing or loose. These aspects complicate the act of successful communication and require additional measures and efforts to involve a person in a dialogue. This paper gives examples of peculiar presenter outfits:

Vladislav Listyev, the program "Chas Pik" ("The Rush Hour") - plain light-colored shirt, colored suspenders (this image is borrowed from the American program "Larry King Live") (Official website "YouTube video hosting. Official video archive of the VID TV company. Peak hour. Issue dated 07.19.1994»);

Valdis Pelsh, the TV game show "Ugaday Melodiyu" ("Guess the Tune") - bright, colored suits, to make the game spectacular and colorful and match the crimson blue studio;

Maria Kiseleva, Nikolai Fomenko, the TV game show "Slaboye Zveno" ("The Weakest Link") - a classic black suit or robe. The style of clothing was developed by the authors of this TV game show format to give the game show a psychological component, discipline, rigor, shock value manifested by the presenter. Chapter 3 provides more detailed information on the image of the "Slaboye Zveno" ("The Weakest Link") presenters.

Sergei Suponev, the entertainment and sports game show for kids "Call of the Jungle" - a hunting hat, brown shorts and a jacket (Official website "YouTube video hosting. Official video archive of the State Television and Radio Fund. Call of the jungle. Issue 1993»). Sergei Suponev conceived this image as a symbol of being one with nature.

7. Setting. One example of competently organized setting is the interview TV show "The Fate of a Man" hosted by Boris Korchevnikov (Official website "YouTube video hosting. The official video archive of the 
Russia-1 TV channel. The fate of a person. Valentin Smirnitsky»).

The nature of communication is determined by the location (studio lighting, temperature, the arrangement of furniture and items, color scheme). However, trustworthy communication requires enclosed space.

Journalist image classification according to E.I. Pronina and E.E. Pronin:

1. Type of contact: friendly, authoritarian, expert (expertise in a narrow field);

2. Level of closeness: hero (an ideal trustworthy personality), antihero (one of us, "one of the guys"), mysterious personality (an unusual and intriguing image for the viewers);

3. Function: "teacher", "leader", "idol", "master", "commander";

4. Way of thinking: "peacemaker", moralist, pragmatist, "player", psychoanalyst [8].

A presenter's image performs several functions. First of all, it allows the presenter to make a statement even before they present information and then guide its perception by the viewers. Additionally, it allows them to focus the audience's attention on the personality traits that are important in a particular context. It also allows them to establish close contact with a specific target audience.

Viewers choose a particular image for a particular person. Charismatic communication style is especially important. J. Goldhaber found that the success of a TV program largely depends on the presenter's charisma (Official website "YouTube video hosting. The official video archive of the Russia-1 TV channel. The fate of a person. Valentin Smirnitsky»).

According to Max Weber, charisma is a quality of a person, by virtue of which they are recognized as gifted with supernatural, superhuman or at least special powers and properties that are inaccessible to other people (Official website «Cyber Leningrad - scientific electronic library. Max Weber's concept of charisma»).

The main characteristic of charismatic people is passionarity (the ability for and urge towards changing the environment) (Official website «Cyberleninka - scientific electronic library. The concept of passionarity in the work of L. N. Gumilyov»).

Types of charisma formation:

1. "Outsider". A person unknown to the viewers, a stranger. They are little-known, strange, and for this reason alone, the audience should pay attention to and listen to them.

2. "Odd". A person with mental or physical disabilities.

3. "Buffoon". This type of image is characterized by extrovert aggressiveness, dynamic behavior, oratory. It is a showman who knows how to keep their audience engaged. Such people are usually involved in the entertainment television sector.

Today, television researchers distinguish three types of charismatic personalities:

1. Hero. They are characterized by aggressive behavior, are self-confident, say what the audience wants to hear. The image of this type of presenter is idealized to the extent of an unattainable ideal. Example: Vladislav Listyev.

2. Antihero. They are slightly above the average viewer, are perceived as an insider, someone who the viewers can emulate, as a friend. Example: Sergei Suponev.

3. Mysterious personality - they are unusual and strange to the viewers, are unpredictable, changeable. Examples: Vladimir Voroshilov, Maria Kiseleva.

\section{CONCLUSION}

Thus, having considered the theoretical aspects of the image of a television presenter, the authors can conclude that the game as one of the key elements of television entertainment has recently been increasingly integrated into journalistic activities, has been evolving, and that new formats of game shows of various types are developed. Furthermore, the presenter or the author and presenter of an intellectual game show must possess a number of certain characteristics: strong communication and psychological skills, provoke in a certain sense of influence onto the player when they have to choose or make a decision, improvisation and intellectual skills, a broad outlook, a sense of humor, charisma; the presenter should be able to establish and maintain contact with a specific audience, including children (if the intellectual game show is intended for kids), generate the viewers' interest, play a particular role in front of the camera or behind the camera and also possess their own unique characteristics to create their own original image. The 
image of an author and presenter performs several functions. First of all, it allows the author and presenter to make a statement even before they present information and then guide its perception by the viewers. Additionally, it allows them to focus the audience's attention on the personality traits that are important in a particular context. The image of an author and presenter also allows them to establish close contact with a specific target audience.

\section{REFERENCE LIST}

1.Vakku, G. V., Zotov, A. E., Lebedeva, S. E. (2020) Professional acting image of the "devil-tempter" performed by the host Leonid Yarmolnik in the TV game "Gold Rush" [Text] / G.V. Wakku, A.E. Zotov, S.E. Lebedeva // Peer-reviewed scientific journal "Trends in the development of science and education." - Samara: Research Center "L-Journal". - 2020. - No 60 (Part 7). - S. 57-59.

2. Official website «Academician - dictionaries and encyclopedias». - URL: http:// dic.academic.ru/dic.nsf/ruwiki/384983.

3. Official website "YouTube video hosting. 25 years of NTV. Dmitry Dibrov's Anthropology program with the King and the Fool group». - URL: http:// youtube.com/watch?v=buJkPQDg508.

4. Official website «YouTube video hosting. Official video archive of the State Television and Radio Fund. Call of the jungle. Issue 1993». - URL: http:// youtube.com/watch?v=A0V9VYi2UhM.

5. Official website «YouTube video hosting. The official video archive of the Russia-1 TV channel. The fate of a person. Valentin Smirnitsky». - URL: http:// Access mode: youtube.com/watch?v=y-e0NNWpX6g.

6. Official website "YouTube video hosting. Official video archive of the VID TV company. Guess the melody. Issue of 27.10.2003». - URL: http:// youtube.com/watch?v=gNILVqnJyZA.

7. Official website «YouTube video hosting. Official video archive of the VID TV company. Peak hour. Issue dated 07.19.1994». - URL: http:// youtube.com/watch?v=CcHj02_tvi0.

8. Official website «Internet archive of educational literature. The psychology of journalism. Study guide». URL: http:// textarchive.ru/c-1612552-p23.html.

9. Official website «Cyberleninka - scientific electronic library. The concept of passionarity in the work of L. N. Gumilyov». - URL: http:// cyberleninka.ru/article/n/kontseptsiya-passionarnosti-v-tvorchestve-I-ngumileva/viewer.

10. Official website «Cyber Leningrad - scientific electronic library. Max Weber's concept of charisma». URL: http:// cyberleninka.ru/article/n/kontseptsiya-harizmy-maksa-vebera/viewer.

\section{Authors}

[1] Corresponding Author Vakku, Grigory Vladislavovich - candidate of philological Sciences, associate Professor, associate Professor of the Department of journalism and editorial and publishing technologies at Moscow state University of Humanities and Economics, Build. 49, 401, Losinoostrovskaya str. Moscow, 107150, Russia; e-mail: vakku2006@rambler.ru

ORCID 0000-0001-7676-8962; SPIN-код: 3886-4740; AuthorID: 284494

[2] Lebedeva, Simona Ernestovna - candidate of philological Sciences, associate Professor of the Department of journalism and editorial and publishing technologies at Moscow state University of Humanities and Economics, Build. 49, 401, Losinoostrovskaya str. Moscow, 107150, Russia; e-mail: lebedeva220461@yandex.ru

SPIN-код: 2308-8043; AuthorID: 929149

[3] Malygina, Lidia Yevgen'yevna - candidate of Philological Sciences, associate Professor, Chair of Russian Language Stylistics, Faculty of Journalism, Lomonosov Moscow State University, Build. 1, St., 9, Mokhovaya str. Moscow, 125009, Russia; e-mail: 9955140@gmail.com

ORCID 0000-0002-0056-8160; D-6901-2019; SPIN-код: 5278 - 1225

[4].Lazutova, Natalia Mikhailovna, senior researcher of the Department of periodicals, Faculty of journalism, Lomonosov Moscow State University, Build. 1, St., 9, Mokhovaya str. Moscow, 125009, Russia; e-mail: n.m.rom@yandex.ru 
ORCID: 0000-0001-7524-1907; SPIN-код: 8551-2698

[5]. Goncharov, Dmitry Konstantinovich, Candidate of Sociological Sciences, Associate Professor of the Department of Informatics of the Russian Economic University G.V. Plekhanov ", house. 36, office 441, Stremyanny lane, Moscow, 117997, Russia; e-mail: vakkmar@mail.ru

ORCID:0000-0002-3408-5036; SPIN-код: 7979-1150; AuthorID: 560483 